\title{
Partial Replacement of Cement Concrete with Rice Husk Ash
}

\author{
S. Vinoth Kumar, Anish . C, Chitra. R
}

\begin{abstract}
To concentrate on the conceivable outcomes of utilizing waste materials from various assembling exercises in the arrangement of cement. The rice husk powder is acquired by consuming rice husk slag in a controlled way without causing natural contamination. The utilization of this waste was proposed in various rates both as an expansion to and rather than bond for the generation of solid blends. In the examination the utilization of rice husk powder has been researched in the solid blends as concrete materials. The examination demonstrated that rice husk fiery debris which are in the residue from could be utilized as cementations material in solid blends where they are accessible and the expense to transportation is lower than common solid materials. The solid is readied containing 10, 20, 30, 40\% misuse of rice husk powder with bond contrasted with the absolute nature of ordinary cement. The readied blends were than concentrated in term of their properties both in new and in solidified state. Specifically, test were led on solidify cement relieved at various occasions in the request to decide their compressive quality with and without incomplete substitution of rice husk powder in concrete were resolved 7days, 14days, 28days
\end{abstract}

Keywords - Waste Materials, Solid Blends, Transportation

\section{INTRODUCTION}

The biological pattern targets restricting the at utilization of normal crude materials in the field of structure materials and consequently there is an expanded enthusiasm for the utilization of elective material (squander) from industrials exercises, which presents critical focal points in financial aspects, vivacious and conditions terms[31]-[34]. Cement is never again made of total, Portland bond and water as it were. Regularly, if not generally it needs to fuse in any event one of the extra fixings, for example, admixtures, valuable concise material or strands to upgrade its quality and sturdiness. The principle worry of utilizing pozzolanic waste was viability as well as to improve the properties of cement, particularly strength[1]-[8].

\section{A. Objectives}

- To study the physical properties of rice husk slag.

- To decide the normal for the rice husk fiery remains with

Revised Manuscript Received on October 22, 2019.

S. Vinoth Kumar, Department of Civil Engineering, Bharath Institute of Higher Education and Research, Chennai, India. Email: vinothsenna@gmail.com

Anish . C, Department of Civil Engineering, Bharath Institute of Higher Education and Research, Chennai, India. Email: anishdavidpaul@gmail.com

Chitra . R, Department of Civil Engineering, Bharath Institute of Higher Education and Research, Chennai, India. Email: chitraroopauma@gmail.com fundamental test.

- To analyze the quality of ordinary cement and the proposed rice husk powder blended cement.

- To analyze the economy of typical cement and the proposed rice husk fiery remains blended cement.

\section{METHODOLOGY}

PLANNING

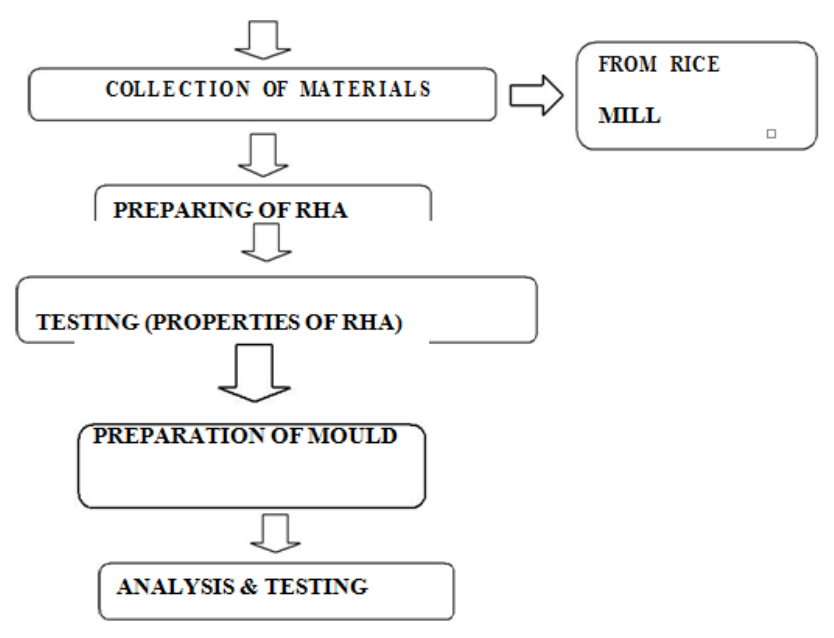

III. RESULTS AND DISCUSSION

Initial test were conducted on cement, sand, coarse aggregate. The results are given below.

A. Rice husk ash:

Specific gravity of $\mathrm{RHA}=2.1$

Bulk density of RHA $=300$ to $400 \mathrm{~kg} / \mathrm{m} 3$

Dry density of RHA $=407 \mathrm{~kg} / \mathrm{m} 3$

Fineness of RHA $=25 \%$

B. Fine aggregate:

Specific gravity $=2.59$

Fineness of fine aggregate $=99.3 \%$ 
Fineness modulus

Specific gravity

\section{Cement:}

\section{E. Mix Design}

Target strength

\section{F. Design Procedure}

\section{Coarse aggregate:}

$=99.25 \%$

Specific gravity $=3.1$

Initial setting time $=30$ minutes

Final setting time $=600$ minutes

Max size of aggregate used

Specific gravity of cement

Specific gravity of sand

Specific gravity of coarse aggregate -
$20 \mathrm{Mpa}$

$20 \mathrm{~mm}$

2.608

2.59

2.3
Calculation of cement, sand, aggregate and ash for one cube.
Grade of concrete

Mix ratio of concrete

Density

Density of concrete

Volume of cube $=150 \mathrm{~mm} * 150 \mathrm{~mm} * 150 \mathrm{~mm}$

$=2400 * 0.15^{3}$

Mass $=8.1 \mathrm{~kg}$

$1 * 8.1$ / 5.5: $1.5 * 8.1 / 5.5: 3 * 8.1 / 5.5$ Amount of cement adding for one cube $=1.5 \mathrm{~kg}$ Amount of fine aggregate adding for one cube $=2.20 \mathrm{~kg}$

Amount of coarse aggregate adding for one cube $=4.42 \mathrm{~kg}$

$10 \%$ of ash will be added $10 / 100 * 1.5=1.35 \mathrm{~kg}$ of cement $\&$ $0.15 \mathrm{~kg}$ ash

\section{Calculation of water content:}

$\mathrm{W} / \mathrm{C}=0.45$

Water content $=0.45 * 1.5$

$=0.675$ litrs.

\section{G. Concrete mix ratio: (FOR ONE CUBE)}

\begin{tabular}{|l|l|l|c|l|l|c|}
\hline MIX & $\begin{array}{c}\text { Cement } \\
(\mathbf{k g})\end{array}$ & RHA(kg) & $\begin{array}{c}\text { Water } \\
(\mathbf{L})\end{array}$ & $\begin{array}{c}\text { Fine } \\
\text { aggregate } \\
(\mathbf{k g})\end{array}$ & $\begin{array}{c}\text { Coarse } \\
\text { aggregate } \\
(\mathbf{k g})\end{array}$ & $\begin{array}{c}\text { W / } \\
\text { Cement } \\
\text { ratio }\end{array}$ \\
\hline CM & 1.5 & 0 & 0.675 & 2.2 & 4.42 & 0.45 \\
\hline $\begin{array}{l}10 \% \\
\text { RHA }\end{array}$ & 1.35 & 0.15 & 0.675 & 2.2 & 4.42 & 0.45 \\
\hline $\begin{array}{l}20 \% \\
\text { RHA }\end{array}$ & 1.2 & 0.3 & 0.675 & 2.2 & 4.42 & 0.45 \\
\hline $\begin{array}{l}30 \% \\
\text { RHA }\end{array}$ & 1.05 & 0.45 & 0.675 & 2.2 & 4.42 & 0.45 \\
\hline $\begin{array}{l}40 \% \\
\text { RHA }\end{array}$ & 0.9 & 0.6 & 0.675 & 2.2 & 4.42 & 0.45 \\
\hline
\end{tabular}

\section{H. Test On Concrete With Rice Husk Ash :}

\section{Slump Test:}

Bottom diameter $\quad: 20 \mathrm{~cm}$

Top diameter $\quad: 10 \mathrm{~cm}$

Height $: 30 \mathrm{~cm}$

\begin{tabular}{|l|l|l|l|}
\hline $\begin{array}{c}\text { Rice husk ash } \\
\%\end{array}$ & \multicolumn{1}{|c|}{$\begin{array}{c}\text { Compressive } \\
\text { strength of } \\
\text { concrete cube } \\
\mathbf{N} / \mathbf{m m}^{2} \mathbf{7} \text { days }\end{array}$} & $\begin{array}{c}\text { Compressive } \\
\text { strength of } \\
\text { concrete cube } \mathbf{N} / \\
\mathbf{m m}^{2} \mathbf{1 4} \text { days }\end{array}$ & $\begin{array}{c}\text { Compressive } \\
\text { strength of } \\
\text { concrete cube } \mathbf{N} \\
/ \mathbf{m m}^{2} \mathbf{2} \text { days }\end{array}$ \\
\hline 0 & 13.33 & 23.2 & 26.12 \\
\hline 10 & 19.33 & 26.22 & 30.66 \\
\hline 20 & 18.22 & 21.11 & 23.11 \\
\hline 30 & 14.02 & 16.88 & 20.3 \\
\hline
\end{tabular}

\section{Comparision Between Ordinary Concrete \& With Rha}

Concrete

- Compare to conventional concrete the construction cost is less[9]-[11].

- Compare to conventional concrete adding RHA of concrete the strength will be increased.

- The addition of admixture is should not be adding on ordinary concrete.

- Small amount of cement is adding on the RHA of concrete.

- Water absorption is will be high on RHA of concrete.

\section{J. COST ANALYSIS}

Cost analysis for addition of $15 \%$ of waste dust in bags of cement.

Weight of cement in $1 \mathrm{bag}=50 \mathrm{~kg}$

Total wt of cement in $10 \mathrm{bags}=50 \mathrm{~kg} * 10$

$=500 \mathrm{~kg}$ 
Totally required cement in addition of $15 \%=500-75 \mathrm{~kg}$ $=425 \mathrm{~kg}$

Cost of 1 bag cement $=$ Rs 350/-

Cost for 10 bags of cement $=$ Rs 3500/-

Cost for $425 \mathrm{~kg}$ of cement $=$ Rs $3050 /-$

Amount saved for 10 bags of cement $=$ Rs $3500-3050$ $=$ Rs 450/-

So for every 10 bags of cement the addition of $15 \%$ of RHA saves Rs.45.

\section{CONCLUSION}

There have been a few potential utilizations of rice husk powder in development industry. Be that as it may, likely because of absence of methodical investigations, enough information is as yet not accessible for its wide spread use in development. The expansion of the squanders improves the physical and mechanical properties. At the point when the squanders are utilized notwithstanding bond up to $15 \%$ can be utilized to give cement of higher physical and mechanical properties[12]-[13].

Because of high fineness of rice husk fiery remains, it demonstrated to be extremely viable in guaranteeing generally excellent cohesiveness of mortar and concrete.Test results show the up to 20 to $30 \%$ of rice husk powder in the bond solid gives the best outcomes.

\section{REFERENCES}

1. Sathish Kumar, K., Vinothkumar, S., Venkatakrishnaiah, R. \& Mohan, S.J. 2019, "Experimental investigation on rehabilitation of corroded concrete beam specimens", International Journal of Civil Engineering and Technology, vol. 10, no. 1, pp. 2949-2955.

2. Kanchanabhan, T.E., Krishnaiah, R.V., Dayakar, P. and Mani, A., 2019. A detailed study on green building concept in construction industry. International Journal of Civil Engineering and Technology, 10(1), pp. 2944-2948.

3. Mugilvani, P., Murugan, S.T., Kaviya, B. and Sathishkumar, K., 2019. Experimental investigation on nano concrete. International Journal of Civil Engineering and Technology, 10(1), pp. 907-912.

4. Vinothkumar, S., Sathishkumar, K., Anish, C. and Rajesh, S., 2019. Characteristic strength of concrete by partial replacement with sawdust and waste ceramic tiles. International Journal of Civil Engineering and Technology, 10(1), pp. 2821-2829.

5. Chitra, R., Thendral, S., Arunya, A. and Mohan, S.J., 2019. Experimental study on strength of concrete by partial replacement of fine aggregate with saw dust. International Journal of Civil Engineering and Technology, 10(1), pp. 2766-2769.

6. Mani, A., Meikandaan, T.P., Gowrishankar, P.G. and Kanchanabhan, T.E., 2019. A study on treatment of industrial effluent (dyeing) using moringa oleifera, tamarina indica as coagulants. International Journal of Civil Engineering and Technology, 10(1), pp. 2796-2811.

7. Frank Stephen, S., Chockalingam, M.P., Nalanth, N. and Lekshmy Raghavan, P., 2019. Study on the fresh state properties of self compacting concrete modified with recycled concrete aggregate. International Journal of Civil Engineering and Technology, 10(1), pp. 1205-1212.

8. Dayakar, P., Raman, K.V., Arunya, A. and Venkatakrishnaiah, R., 2019. Study on strength properties of sand by biocementation with eggshell. International Journal of Civil Engineering and Technology, 10(1), pp. 2770-2785.
9. Shendge, R.B., Chockalingam, M.P., Saritha, B. and Ambica, A. 2018. Swat modelling for sediment yield: A case study of Ujjani reservoir in Maharashtra, India. International Journal of Civil Engineering and Technology, 9(1), pp. 245-252.

10. Meikandaan, T.P. and Hemapriya, M., 2017. Use of glass FRP sheets as external flexural reinforcement in RCC Beam. International Journal of Civil Engineering and Technology, 8(8), pp. 1485-1501

11. Harini, A.T., 2017. Experimental study on utilisation of ceramic wastes in concrete. International Journal of Civil Engineering and Technology, 8(8), pp. 1346-1352.

12. Ambica, A., Sartiha, B. and Anbarasan, R., 2017. Groundwater quality assessment using water quality index and GIS, Maduravoyal, Chennai, India. International Journal of Civil Engineering and Technology, 8(8), pp. 1375-1381.

13. Aswathy, M., Saritha, B. and Chockalingam, M.P., 2019. Degradation of anionic dye using Fe/Tio2 composite by photocatalysis. International Journal of Innovative Technology and Exploring Engineering, 8(9 Special Issue 3), pp. 788-791

\section{AUTHORS PROFILE}

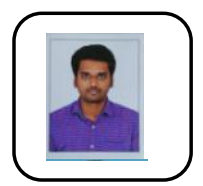

S. Vinoth Kumar Assistant Professor Department of Civil Engineering, Bharath Institute of Higher Education and Research, Chennai , India.

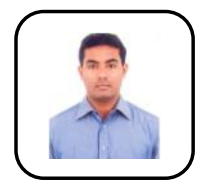

Anish . C Assistant Professor, Department of Civil Engineering, Bharath Institute of Higher Education and Research, Chennai , India.

Chitra. R Assistant Professor, Department of Civil Engineering, Bharath Institute of Higher Education and Research, Chennai, India. 